\title{
Kollegial supervision som udviklingsredskab i undervisningskulturer
}

\author{
Anmeldelse af Camilla Østerberg Rump, Institut for Naturfagenes Didaktik, Kфben- \\ havns Universitet
}

Hanne Leth Andersen og Lene Tortzen Bager (red.):

Kollegial Supervision som udviklingsredskab i undervisningskulturer.

Aarhus Universitetsforlag, 2011.

119 sider.

Bogen samler op på forfatternes og andres videre arbejde med metoden kollegial supervision, som er et redskab til undervisningsudvikling, der blev udviklet med udgangspunkt $i$ et forløb på Aarhus Universitets humanistiske fakultet. Bogen starter med en kort, målrettet og to the point-introduktion til metoden, som er lige til at gå til, hvis man selv vil gå i gang. Herefter følger en række mangeartede, korte og overskuelige beskrivelser af erfaringer med metoden fra dels underviserperspektiv, dels ledelsesperspektiv. Til sidst i bogen er der en materialesamling, som kan bruges, hvis man selv vil arbejde videre med metoden.

Metoden bygger på fokuseret observation og anerkendende samtale. Udgangspunktet er undervisernes praksis for at skabe et fortroligt rum for udvikling, udveksling og vidensdeling om undervisning, og for samtidig at udvikle deltagernes dialogiske kompetence. Metoden er, at tre kolleger på skift: 1) Udvælger fokus for observation og udvikling; 2) observerer undervisning ud fra det valgte fokus; 3) gennemfører en samtale/dialog med henblik på at skabe refleksion for den enkelte; og 4) reflekterer over metoden og over den viden, der udvikles og opbygges hos den enkelte og i gruppen. De tre kolleger skiftes til at være henholdsvis fokusperson (den underviser, hvis undervisning bliver observeret), supervisor (der fører udviklingssamtalen), og mediator (der observerer og giver feedback på samtalen). Rammen for samtalen er den 'anerkendende samtale', i hvilken der bevidst fokuseres overvejende på det, der virker frem for på eventuelle problemer, for på den måde at udvikle den praksis hos underviseren, han eller hun faktisk har succes med. Metoden er relativt stringent, og det er en pointe i sig selv. Intentionen er dels at sikre, at deltagerne ikke overskrider hinandens personlige grænser, dels at sikre, at alle gruppemedlemmer kan deltage ligeværdigt uden at skulle evaluere eller bedømme hinanden. 
Bogen er en rigtig god bog - både set fra et praktikerperspektiv, og hvis man er interesseret i de mere metodiske og teoretiske betragtninger bag. De mange praktikerbeskrivelser kan sagtens læses enkeltstående, hvis man fx er interesseret i en kort beskrivelse af nogle erfaringer fra arbejdet med metoden i en institutionel ramme, der er lig ens egen, fordi alle beskrivelserne indledes med en beskrivelse af netop den institutionelle ramme. Men samlet set udgør beskrivelserne en kaleidoskopisk oversigt over de barrierer og udfordringer og samtidig løsninger og gode erfaringer, som man kunne tænkes at skulle forholde sig til, hvis man selv vil gøre sig erfaringer med kollegial supervision. Det overlades til læseren at danne sig et samlet overblik over feltet, og det mener jeg egentlig er en styrke, for læseren skal alligevel selv gøre arbejdet med at fortolke erfaringerne i forhold til sin egen institution.

Fra et universitetsunderviserperspektiv er der særlig grund til at fremhæve to praksisbeskrivelser. Den ene er fra Købehavns Universitets humanistiske fakultet, og beskriver meget loyalt og præcist hvilke barrierer og vanskeligheder, der kan vise sig i en organisation, der er under pres, og hvor medarbejderne af forskellige årsager fra starten har svært ved at tage ejerskab til projektet. Set i kontrast til den anden beskrivelse fra Rytmisk Musikkonservatorium, beskriver den også en for universiteterne ikke helt atypisk underviserkultur, hvor undervisningsudvikling ikke ses som en naturlig og nødvendig del af det akademiske virke: "Hvorfor udvikle noget der virker?" Og hvor der samtidig er en vis blufærdighed hos mange omkring den privatpraktiserede undervisning og endog angst forbundet med at skulle åbne døren til klasselokalet.

På Rytmisk Musikkonservatorium har man derimod formået at forbinde udviklingen af undervisningen gennem kollegial supervision med den udvikling af undervisernes professionelle kunstneriske praksis, der finder sted i bandet:

"Den enkelte rytmiske musiker med sin særlige kunnen og viden oplever sig som en kompetent og essentiel del af bandets kunstneriske arbejdsfællesskab. Samtidig kan bandet kun skabe ny kunst, hvis den enkelte i de kunstneriske processer 'underlægger sig' det fælles kunstneriske udtryk og ser sig som potentielt 'i bevægelse' [...]. Der lader mao. ikke til at være en modsætning mellem på den ene side at være kompetent og selvstændig kunstner og på den anden side at være åben og undersøgende."

Afsnittet forbinder på blændende og letlæst vis, hvordan den kollegiale supervision kan ses som en ramme, hvor den enkelte kan være 'kompetent usikker' og dermed give sig selv og sine kolleger adgang til læring og nye handlemuligheder. Hvis man nu så 'bandet' som 'det forskningsmæssige eller videnskabelige fællesskab', og 'kunst' som 'ny viden' i ovenstående - kunne det mon så ikke tilsvarende for andre 
universitære institutioner være en vej ind i kollegavejledning, at den kompetente og selvstændige forsker kunne være åben og undersøgende i forhold til sin egen og andres undervisning?

Jeg og mine kolleger har selv i en årrække arbejdet med kollegavejledning, som den er udviklet af Per Lauvås og Gunnar Handal, der, som Lene Tortzen Bager beskriver, bygger på de samme grundsten som kollegial supervision. Vi har mange tilsvarende erfaringer som de, der beskrives i bogen. Men særligt har vi gode erfaringer med at bruge kollegavejledning som en integreret del af vores Adjunktpædagogikum (og til dels i vores ph.d.-vejledningskurser). Det betyder, at underviserne fra starten får erfaring med at åbne døren til undervisningslokalet for kolleger, i dette tilfælde deres medkursister, og med at udvikle, udveksle og vidensdele med kolleger. Det betyder ikke, som enhver læser af bogen vel ikke vil være overrasket over, at der derefter spontant opstår kollegavejledningsgrupper på deres institutioner efterfølgende. Men det betyder forhåbentlig, at vejen er banet på længere sigt for en undervisningskultur der er åben og undersøgende i forhold til undervisning og dermed kan udnytte det fulde potentiale af tiltag, der bygger på kollegial supervision eller kollegavejledning.

I øvrigt tror jeg, man med fordel kunne udvikle begge metoder yderligere ved - så at sige - at tage det bedste fra de to metoder: Førvejledningssamtale med vejledningsgrundlag fra kollegavejledningen, og den anerkendende samtale fra kollegial supervision. Men det er en helt anden historie. 